\title{
PENGETAHUAN DAN PRAKTEK HYGIENE PENJAMAH PADA PEDAGANG MAKANAN JAJANAN DI SEKITAR SEKOLAH DASAR KOTA TASIKMALAYA
}

\section{KNOWLEDGE AND PRACTICE OF HYGIENE ON THE MERCHANT PENJAMAH HAWKER FOOD AROUND TASIKMALAYA TOWN PRIMARY SCHOO}

\author{
Sri Maywat ${ }^{1}$, Lilik Hidayanti, Nur Lina ${ }^{2}$ \\ 1,2 Fakultas Ilmu Kesehatan Universitas Siliwangi \\ srimaywati@unsil.ac.id
}

\begin{abstract}
ABSTRAK
Anak sekolah merupakan kelo mpok yang rentan mengala mi gangguan kesehatan yang dibawa oleh makanan yang dikelola secara tidak sehat yang berkaitan dengan pengelolaan oleh penjamah makanan. Pengetahuan dan praktek penjamah mengenai hygiene penjamah menjadi hal yang penting. Tujuan penelitian ini untuk menganalisis hubungan pengetahuan dengan praktek hygiene penjamah makanan jajanan di sekitar sekolah dasar kota Tasikmalaya. Penelitian menggunakan metode survei dengan pendekatan cross sectional. Sampel dipillih secara acak dari penjamah makanan dengan jenis kelamin laki-laki yang berjualan di sekitar sekolah dasar sebanyak 65 orang. Data dikumpulkan dengan teknik wawancara dan observasi, selanjutnya analisis data menggunakan uji chi square. Hasil penelitian menunjukkan terdapat hubungan yang signifikan $(\mathrm{p}<0,05)$ antara pengetahuan tentang hygiene penjamah dengan praktek hygiene penjamah pada pedagang makanan jajanan di sekitar sekolah dasar. Disarankan kepada pedagang untuk meningkatkan pengetahuan dan praktek hygiene yang baik melalui berbagai media informasi.

Kata kunci : pengetahuan, praktek, hygiene, penjamah
\end{abstract}

\section{ABSTRACT}

School children are a group that is susceptible to health problems brought by unhealthy food that is related to management by food vendoors. Knowledge and practice of food vendors regarding vendors hygiene is important. The purpose of this study was to analyze the relationship between knowledge with hygiene practices of food vendors around the elementary schools of the city of Tasikmalaya. The study used a survey method with a cross sectional design. Samples were choosen by randomly from food vendoors with criteria is male and selling around elementary school as many as 65 people. Data was collected by interviewied and observation techniques, then analyzedwhith chi square test. The results showed that there was a significant relationship $(p<0.05)$ between knowledge of food vendoors hygiene and the hygiene practices of the food vendors on around elementary schools. It is recommended to food vendors to improve their knowledge and good hygiene practices through various information media.

Key words : knowledge, practice, hygiene, food vendors 


\section{LATAR BELAKANG}

Makanan jajanan merupakan makanan yang dipersiapkan dan dijual oleh pedagang kaki lima di jalanan dan tempat - tempat keramaian umum lain yang langsung dimakan atau dikonsumsi tanpa pengolahan atau persiapan lebih lanjut.Murphy \& Allen, 2007 dalam Hapsari (2013). Makanan jajanan ini sering dijumpai di keramaian termasuk di lingkungan sekolah. Wang, et al (2016) menyebutkan makanan jajanan (ngemil) merupakan penyumbang penting energi dan nutrisi pada makanan anak-anak, namun makanan dan minuman yang dipilih bervariasi menurut waktu dan usia. Memodifikasi pilihan ngemil, terutama di siang hari, bisa meningkatkan kualitas gizi makanan anak-anak.

Beberapa manfaat dapat diperoleh dari konsumsi makanan jajanan, namun seringkali juga konsumen mendapatkan dampak negatif dari makanan jajanan yang dikelola secara tidak sehat. Makanan jajanan yang tidak sehat seringkali berkaitan dengan penglolaan oleh penjamah makanan. Pengetahuan penjual makanan tentang hygiene dan sanitasi pengolahan makanan akan sangat mempengaruhi kualitas makanan yang disajikan kepada masyarakat konsumen. Fowora (2012) dalam Adebukola (2015) menyebutkan pengetahuan tentang penanganan makanan dan infeksi yang ditularkan melalui makanan dan praktik keselamatan mereka merupakan isu penting dalam wabah infeksi yang ditularkan melalui makanan.

Persyaratan sanitasi makanan jajanan telah diatur dalam Keputusan Menteri Kesehatan Republik Indonesia Nomor 942/Menkes/Sk/Vii/2003, mengatur sanitasi makanan jajanan meliputi perilaku penjamah, peralatan, air dan bahan makanan, serta sarana penjaja makanan. Merujuk pada peraturan tersebut, maka penerapan higiene sanitasi pada pedagang makanan menjadi hal yang penting bagi keamanan pangan yang dikonsumsi oleh masyarakat. Upaya penerapan higiene sanitasi salah satunya dipengaruhi oleh tingkat pengetahuan pedagang dalam pengelolaan makanan jajanan mulai proses produksi sampai penyajian makanan jajanan.

Tingkat pengetahuan seseorang akan diimplementasikan dalam bentuk tindakan. Penelitian yang dilakukan oleh Avrilinda (2016) pada kantin sekolah di Surabaya menunjukkan terdapat pengaruh pengetahuan terhadap perilaku higienis penjamah makanan.Faktor kebersihan penjamah atau petugas makanan dalam istilah populernya disebut higiene perorangan merupakan prosedur menjaga kebersihan dalam pengelolaan makanan yang aman dan sehat untuk mencegah kontaminasi pada makanan yang ditangani, seperti pencucian tangan, kebersihan dan kesehatan diri.

Hasil survei pendahuluan yang dilakukan oleh penulis menggambarkan keadaan penjamah makanan jajanan yang berjualan di sekitar sekolah dasar antara lain memiliki kuku panjang, merokok sambil melayani pembeli, tidak menggunakan tutup kepala, memegang makanan secara langsung tanpa alat bantu. Berdasarkan kondisi tersebut, peneliti tertarik meneliti mengenai pengetahuan dan praktek penjamah makanan jajanan sekolah di kota Tasikmalaya.

\section{METODE PENELITIAN}

Penelitian ini menggunakan metodesurveidenganpendekatanbelah lintang (crosssectional). Variabel bebas (Independen)yaitufaktorpengetahuanped 
agang tentang higiene penjamah. Variabelterikat(Dependent)yaitu praktekhigiene penjamah makanan. Variabelpengganggu adalah tingkat pendidikan responden. Data dikumpulkan menggunakan lembar kuesiner dan lembar observasi praktek. Sampel sebanyak 65 responden yang merupakan bagian dari populasi yaitu pedagangmakananjajananyangberjualan disekitarsekolahdasard ikeca matanTawa ng kota Tasikmalaya. Kriteriainklusisampeladalahpedagang laki-laki, pedagang menjualmakanan jajanandisekitarsekolah.Kriteria ekslusiadalahpedagangmenolakmenjadir esponden. Analis is statistikyang digunakanadalahujiChi Squarepada tingkatkemaknaanyangdigunakanCI95\% dengan alpha 0,05.

\section{HASIL DAN PEMBAHASAN}

\subsection{Analis is Univariat}

\subsubsection{Umur}

$$
\text { Hasil }
$$

penelitian

menunjukkan pedagang makanan jajanan yang berjualan di sekitar sekolah dasar memiliki rentang usia antara 18 tahun sampai 65 tahun. Rerata usia responden adalah 38,4 tahun dengan standar deviasi 1,15. Secara umum, usia responden termasuk dalam usia produktif yang melakukan aktifitas pekerjaan yang menghasilkan secara ekonomi. Pekerjaan menjual makanan jajanan yang dilakukan oleh responden umumnya menjadi pekerjaan utama untuk mendapatkan penghasilan. Menurut Suryabudhi (2003) menyatakan bahwa semakin lama hidup maka pengalaman semakin banyak, pengetahuan semakin luas, keahliannya semakin mendalam dan kearifannya semakin baik dalam pengambilan keputusan tindakannya.
3.1.2 Tingkat pendidikan responden

Tabel 1. Distribusi Frekuensi Tingkat Pendidikan Responden Pedagang Makanan Jajanan Sekitar Sekolah Dasar di Kota

\begin{tabular}{llll}
\multicolumn{4}{c}{ Tasikmalaya, 2018} \\
\hline No & \multicolumn{1}{c}{ Tingkat } \\
& pendidikan & $\mathrm{f}$ \\
\hline 1. & SD & 30 & 46,2 \\
2. & SMP & 25 & 38,5 \\
3. & SMA & 10 & 15,4 \\
\hline & Jumlah & 65 & 100,0 \\
\hline
\end{tabular}

Tabel di atas menunjukkan sebagian besar tingkat pendidikan responden adalah SD sebesar 46,2 \%. Tingkat pendidikan akan mempengaruhi pola pikir dan perilaku seseorang.

\subsubsection{Sarana Berjualan}

Tabel 2. Distribusi Frekuensi Sifat Berjualan Pedagang Makanan Jajanan Sekitar Sekolah Dasar di Kota Tasikmalaya, 2018

\begin{tabular}{llcc}
\hline No & Sarana berjualan & $\mathrm{f}$ & $\%$ \\
\hline 1. & $\begin{array}{l}\text { gerobak/ } \\
\text { keranjang (sifat } \\
\text { tidak menetap }\end{array}$ & 49 & 75,4 \\
2. & $\begin{array}{l}\text { Warung/ tenda } \\
\text { (sifat menetap) }\end{array}$ & 16 & 26,4 \\
\hline & Jumlah & 65 & 100,0 \\
\hline
\end{tabular}

Tabel di atas menunjukkan sebagian besar $(75,4 \%)$ responden melakukan aktivitas berjualan secara tidak menetap dengan menggunakan gerobak atau keranjang sebagai sarana berjualan. Cara berjualan menggunakan gerobak atau kerangjang menunjukkan responden yang tidak menetap dalam berjualan sehingga ada kemungkinan dapat pindah lokasi ke tempat lain. kondisi seperti ini umumnya akan menyulitkan dalam pembinaan pedagang makanan jajanan anak sekolah. 


\subsubsection{Waktu Berjualan Makanan}

Tabel 3. Distribusi Frekuensi Waktu

Berjualan Pedagang Makanan Jajanan Sekitar Sekolah Dasar di Kota

Tasikmalaya, 2018

\begin{tabular}{lllc}
\hline No & waktu berjualan & $\mathrm{F}$ & $\%$ \\
\hline 1. & $\begin{array}{l}\text { Kadang di sekolah } \\
\text { Setiap hari di }\end{array}$ & 95 & 13,8 \\
& $\begin{array}{l}\text { sekolah yang sama } \\
\text { Jumlah }\end{array}$ & 65 & 100,0 \\
\hline
\end{tabular}

Hasil penelitian menunjukkan sebagian besar pedagang melakukan aktivitas berjualan setiap hari di sekolah yang sama sebesar 86,2 \%. Secara umum responden melakukan aktivitas berjualan di sekolah yang sama setiap hari. Jadi walaupun berjualan menggunakan sarana yang dapat berpindah seperti gerobak atau keranjang, namun responden kembali berjualan di lokasi yang sama di esok hari.

\subsubsection{Pengetahuan Responden} Mengenai Higiene Penjamah

Tabel 4. Gambaran jawaban responden mengenai pengetahuan hygiene penjamah makanan di sekitar sekolah dasar kota Tasikmalaya

\begin{tabular}{|c|c|c|c|c|c|}
\hline $\begin{array}{l}\mathrm{N} \\
0\end{array}$ & $\begin{array}{c}\text { Item } \\
\text { pertanyaan } \\
\text { pengetahua } \\
\text { n higiene } \\
\text { penjamah }\end{array}$ & & $\%$ & $\begin{array}{c}\text { Tida } \\
\text { k }\end{array}$ & $\%$ \\
\hline 1. & $\begin{array}{l}\text { Persyaratan } \\
\text { higiene } \\
\text { penjamah ? } \\
\text { a. Persyar } \\
\text { atan } \\
\text { penjam } \\
\text { ah harus } \\
\text { memoto } \\
\text { ng kuku } \\
\text { secara } \\
\text { rutin } \\
\text { b. Penjam } \\
\text { ah tidak } \\
\text { menderi }\end{array}$ & $\begin{array}{l}1 \\
8 \\
1 \\
1 \\
5 \\
3\end{array}$ & $\begin{array}{l}41, \\
5 \\
27, \\
7 \\
16, \\
9 \\
81, \\
5 \\
86, \\
2 \\
63,\end{array}$ & $\begin{array}{l}38 \\
47 \\
54 \\
12 \\
9 \\
24\end{array}$ & $\begin{array}{l}58, \\
5 \\
72, \\
3 \\
83, \\
1 \\
18, \\
5 \\
13, \\
8 \\
36,\end{array}$ \\
\hline
\end{tabular}

\begin{tabular}{|c|c|c|c|c|c|c|}
\hline & c. & $\begin{array}{l}\text { ta } \\
\text { penyaki } \\
\mathrm{t} \\
\text { menular } \\
\text { Penjam } \\
\text { ah tidak } \\
\text { mempu } \\
\text { nyai } \\
\text { kutu } \\
\text { rambut } \\
\text { Penjam } \\
\text { ah tidak } \\
\text { boleh } \\
\text { batuk/b } \\
\text { ersin } \\
\text { saat } \\
\text { melaya } \\
\text { ni } \\
\text { (didepa } \\
\text { n } \\
\text { makana } \\
\text { n) } \\
\text { Penjam } \\
\text { ah } \\
\text { boleh } \\
\text { meroko } \\
\text { k saat } \\
\text { berjuala } \\
\mathrm{n} \\
\text { Penjam } \\
\text { ah } \\
\text { boleh } \\
\text { mengga } \\
\text { ruk } \\
\text { bagian } \\
\text { tubuh } \\
\text { saat } \\
\text { menang } \\
\text { ani } \\
\text { bahan } \\
\text { makana } \\
\text { n }\end{array}$ & $\bar{~} 1$ & $\bar{~} 1$ & & 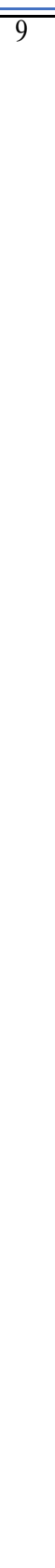 \\
\hline 2. & $\begin{array}{l}\mathrm{K} \\
\mathrm{se} \\
\mathrm{p} \\
\mathrm{m} \\
\text { ta } \\
\mathrm{a} .\end{array}$ & $\begin{array}{l}\text { apan } \\
\text { baiknya } \\
\text { enjamah } \\
\text { encuci } \\
\text { ngan? } \\
\text { Setelah } \\
\text { menyen } \\
\text { tuh } \\
\text { bahan } \\
\text { mentah } \\
\text { Sebelu } \\
\text { m } \\
\text { memeg }\end{array}$ & $\begin{array}{l}2 \\
2 \\
1 \\
6 \\
1 \\
3 \\
\\
3 \\
5 \\
1 \\
0 \\
3\end{array}$ & $\begin{array}{l}33, \\
8 \\
24, \\
6 \\
20, \\
0 \\
53, \\
8 \\
15, \\
4 \\
60,\end{array}$ & $\begin{array}{l}43 \\
49 \\
52 \\
\\
30 \\
55 \\
26 \\
52\end{array}$ & $\begin{array}{l}66, \\
2 \\
75, \\
4 \\
80, \\
0 \\
46, \\
2 \\
84, \\
5 \\
40,\end{array}$ \\
\hline
\end{tabular}




\begin{tabular}{|c|c|c|c|c|c|}
\hline & \begin{tabular}{|ll} 
& ang \\
& makana \\
& n \\
& matang \\
c. & Setelah \\
& memeg \\
& ang \\
& tubuh \\
& dan \\
& benda \\
& di \\
& sekitarn \\
& ya \\
d. & Setelah \\
& memeg \\
& ang \\
& sampah \\
e. & Setelah \\
& batuk/b \\
f. & ersin \\
f. & Setelah \\
& menggu \\
& nakan \\
g. & toilet \\
getelah & memeg \\
& ang \\
uang
\end{tabular} & $\begin{array}{l}9 \\
1 \\
3\end{array}$ & $\begin{array}{l}0 \\
20, \\
0\end{array}$ & & $\begin{array}{l}0 \\
80, \\
0\end{array}$ \\
\hline 3. & \begin{tabular}{|ll}
\multicolumn{1}{|c}{ Pers yaratan } \\
pakaian dan \\
penampilan \\
a. & Penjam \\
& ah \\
& sebaikn \\
& ya \\
& menggu \\
& nakan \\
& celemek \\
b. & Penjam \\
& ah \\
& sebaikn \\
& ya \\
menutu \\
p kepala \\
c. Penjam \\
ah harus \\
berpena \\
mpilan \\
bersih \\
d. Penjam \\
ah tidak \\
boleh \\
menggu \\
nakan \\
perhiasa
\end{tabular} & $\begin{array}{l}2 \\
4 \\
1 \\
4 \\
5 \\
6 \\
3 \\
0 \\
5 \\
0\end{array}$ & $\begin{array}{l}36, \\
9 \\
21, \\
5 \\
86, \\
2 \\
46, \\
2 \\
76, \\
9\end{array}$ & $\begin{array}{l}41 \\
51 \\
9 \\
35 \\
15\end{array}$ & $\begin{array}{l}63, \\
1 \\
78, \\
5 \\
13, \\
8 \\
53, \\
8 \\
23, \\
1\end{array}$ \\
\hline
\end{tabular}
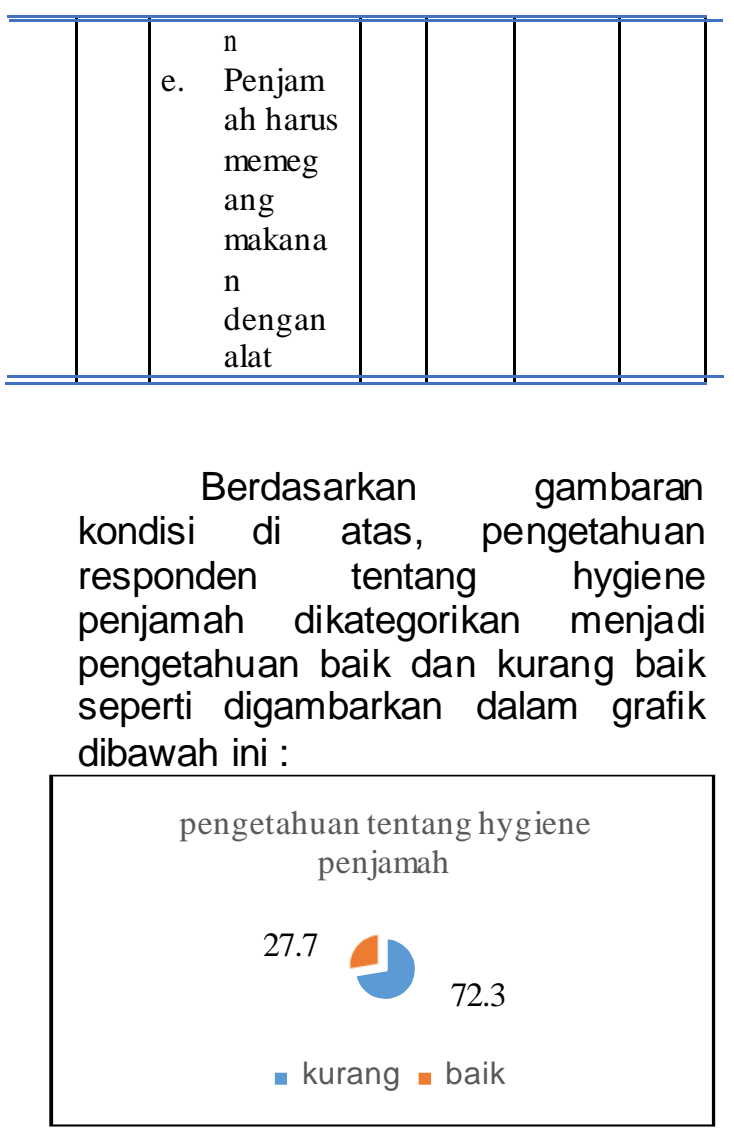

Gambar 1. Distribusi berdasarkan kategori pengetahuan mengenai hygiene penjamah pedagang jajanan di sekitar sekolah das ar kota Tasikmalaya

Penjamah makanan jajanan adalah orang yang secara langsung atau tidak langsung berhubungan dengan makanan dan peralatannya sejak dari tahap persiapan, pembersihan, pengolahan, pengangkutan sampai dengan penyajian. Berdasarkan persyaratan penjamah makanan sesuai Permenkes no 942 tahun 2003 menyebutkan Penjamah makanan jajanan dalam melakukan kegiatan pelayanan penanganan makanan jajanan harus memenuhi persyaratan antara lain a) tidak menderita penyakit mudah menular misal : batuk, pilek, influenza, diare, penyakit perut sejenisnya; b) menutup luka (pada luka terbuka/ 
bisul atau luka lainnya); c) menjaga kebersihan tangan, rambut, kuku, dan pakaian; d) memakai celemek, dan tutup kepala; e) mencuci tangan setiap kali hendak menangani makanan; f) menjamah makanan harus memakai alat/ perlengkapan, atau dengan alas tangan; g) tidak sambil merokok, menggaruk anggota badan (telinga, hidung, mulut atau bagian lainnya); h) tidak batuk atau bersin di hadapan makanan jajanan yang disajikan dan atau tanpa menutup mulut atau hidung.

Gambaran pengetahuan responden tentang higiene penjamah antara lain masih terdapat $58,5 \%$ responden yang belum mengetahui bahwa persyaratan penjamah harus memotong kuku secara rutin, belum mengetahui bahwa syarat penjamah tidak boleh memiliki penyakit menular sebanyak 72,3\%, tidak mengetahui bahwa syarat penjamah tidak boleh memiliki kutu rambut $(83,1 \%)$, masih terdapat penjamah yang belum mengetahui bahwa penjamah tidak boleh batuk/bersin saat menangani makanan sebanyak $81,5 \%$ serta masih terdapat penjamah menyatakan boleh merokok saat berjualan sebanyak 86,2\%.

Pengetahuan penjamah

mengenai cuci tangan dalam menangani makanan, antara lain terdapat lebih dari setengah responden menyatakan tidak mengetahui waktu-waktu yang sebaiknya penjamah mencuci tangan seperti saat setelah memegang bahan mentah, sebelum memegang makanan matang, setelah memegang bagian tubuh dan benda di sekitar, setelah batuk/bersin, serta setelah memegang uang.
Pengetahuan penjamah mengenai kebersihan dan penampilan diperoleh gambaran terdapat lebih dari setengah responden yang menyatakan tidak mengetahui bahwa penjamah seharusnya menggunakan celemek $(63,1 \%)$, tidak mengetahui penjamah seharusnya menutup kepala $(78,5 \%)$, terdapat $53,8 \%$ responden yang belum mengetahui tentang penjamah tidak boleh menggunakan perhiasan.

Pengetahuan mengenai

hygiene penjamah dan sanitasi makanan jajanan dapat diperoleh dari berbagai sumber media informasi.

Institusi terkait seperti dinas kesehatan dapat melakukan kegiatan pembinaan seperti pelatihan maupun memberikan penyuluhan kepada pedagang makanan jajanan. Selain itu, pihak institusi sekolah juga dapat memberikan pemantauan terhadap para pedagang makanan jajanan yang berjualan di sekitar sekolah.

\subsubsection{Praktek Hygiene Penjamah Makanan}

Gambaran mengenai praktek penjamah pada pedagang jajanan makanan di sekitar sekolah dasar kota Tasikmalaya dapat dilihat pada grafik berikut:

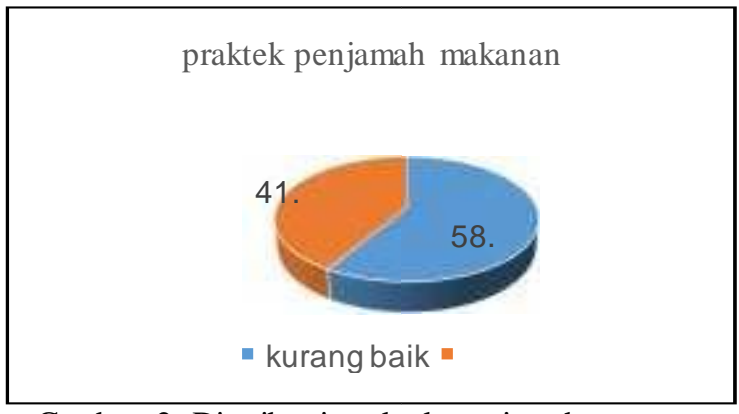

Gambar 2. Dis tribusi praktek penjamah makanan jajanan di sekitar sekolah das ar kota Tasikmalaya 
Berdasarkan observasi yang dilakukan kepada pedagang makanan saat berjualan di peroleh gambaran mengenai praktek responden yang kurang baik terutama berkaitan dengan tidak menggunakan celemek $(89,2 \%)$, tidak menggunakan tutup kepala $(64,6 \%)$, masih terdapat responden yang sering batuk/bersin saat menangani makanan(18,5\%), terdapat responden yang menggaruk bagian tubuh $(16,9 \%)$, tidak mencuci tangan setelah memegang uang (78,5\%)maupun sebelum menangani makanan $(32,2 \%)$, serta masih terdapat sebagian kecil responden yang menggunakan perhiasan pada tangan seperti cincin $(16,9 \%)$ dan yang memiliki kuku panjang $(32,3 \%)$ serta masih terdapat penjamah yang terlihat memiliki kuku kotor $(24,6 \%)$.

\subsection{Analis is bivariat}

Tabel 4. Tabulasi Silang Hubungan Tingkat Pengetahuan Dengan Praktek Penjamah

Makanan pedagang Jajanan

Di Sekitar Sekolah Dasar

Kota Tasikmalaya, 2018

\begin{tabular}{|c|c|c|c|c|c|c|}
\hline \multirow{4}{*}{$\begin{array}{l}\text { Kategori } \\
\text { Pengetah } \\
\text { uan }\end{array}$} & \multirow{2}{*}{\multicolumn{2}{|c|}{$\begin{array}{l}\text { Kategori } \\
\text { Penjamah }\end{array}$}} & \multirow{2}{*}{\multicolumn{2}{|c|}{ Praktek }} & \multicolumn{2}{|c|}{ Jumlah } \\
\hline & & & & & & \\
\hline & \multicolumn{2}{|c|}{$\begin{array}{l}\text { Kurang } \\
\text { baik }\end{array}$} & \multicolumn{2}{|l|}{ Baik } & & \\
\hline & $\mathrm{f}$ & $\%$ & $\mathrm{f}$ & $\%$ & $\mathrm{f}$ & $\%$ \\
\hline \multirow{2}{*}{ Kurang } & \multirow[t]{2}{*}{32} & 68 & 15 & 31 & 4 & 10 \\
\hline & & , 1 & & ,9 & 7 & 0,0 \\
\hline \multirow[t]{2}{*}{ Baik } & \multirow[t]{2}{*}{6} & 33 & 12 & 66 & 1 & 10 \\
\hline & &, 3 & &, 7 & 8 & 0,0 \\
\hline \multirow[t]{2}{*}{ Jumlah } & \multirow[t]{2}{*}{38} & 58 & 27 & 41 & 6 & 10 \\
\hline & &, 5 & &, 5 & 5 & 0,0 \\
\hline
\end{tabular}

Berdasarkan analisis statistik menggunakan uji chi square diperoleh hasil $p$ value sebesar0,024 yang artinya terdapat hubungan signifikan antara tingkat pengetahuan dengan praktek penjamah pada pedagang makanan jajanan di sekitar sekolah dasar kota
Tasikmalaya. Resiko pedagang yang memiliki tingkat pengetahuan kurang adalah sebesar 4,267 kali melakukan praktek penjamah yang kurang baik.

Pengetahuan adalah luasnya wawasan seseorang mengenai sesuatu hal. Pengetahuan sangat diperlukan dalam melakukan berbagai hal, termasuk juga pengetahuan pedagang mengenai hygiene penjamah dalam menangani makanan jajanan. Pengetahuan yang baik akan berdampak pada praktek pengelolaan makanan yang baik sehingga dapat terhindar dari terjadinya kontaminasi pada bahan makanan. Pengetahuan didapatkan dari teori dan pengalaman yang pernah dilakukan individu bersangkutan serta faktor pendidikan. Salah satu faktor yang dapat mempengaruhi pengetahuan adalah tingkat pendidikan responden. Budiyono (2009) menyatakan bahwa pendidikan yang tinggi akan lebih mempermudah individu bersangkutan untukmelakukan analisis terkait kondisi yang dihadapi,dalam hal ini tenang hygiene dan sanitasi makanan

Hasil penelitian menggambarkan pada responden yang memiliki pengetahuan yang kurang mengenai hygiene penjamah akan melakukan aktivitas yang kurang baik juga saat berjualan seperti merokok saat berjualan maupun batuk/bersin saat menangani bahan makanan. Hal ini bisa menjadi media penularan penyakit yang mengkontaminasi pada bahan makanan seperti yang umum dikenal food borne desease.

Praktek penjamah yang lainnya seperti praktek mencuci tangan yang kurang baik antara lain tidak mencuci tangan setelah menyentuh bagian tubuh, tidak mencuci tangan sebelum memegang makanan maupun setelah memegang uang. Hasil penelitian ini 
senada dengan Agustina, dkk (2010) yang menyatakan sebagian besar $(86,9 \%)$ responden tidak mencuci tangan saat hendak menjamah makanan. BPOM (2002), menjelaskan bahwa semua pekerja yang menjamah makanan harus mencuci tangan dengan air yang bersih bersuhu $40^{\circ} \mathrm{C}-49^{\circ} \mathrm{C}$ dengan sabun. Mencuci tangan dengan sabun dapat mencegah terjadinya perpindahan kontaminan dari tangan ke bahan makanan. Penelitian Desiyanto (2013) menunjukkan bahwa mencuci dengan air dan sabun atau hand sanitizer terbukti efektif dalam mengurangi jumlah mikroorganisme dikarenakan sabun mengandung zat anti kuman atau desinfektan. Menurut Sari (2016) menyatakan praktek responden yang tidak mencuci tangan saat menyentuh makanan dapat menyebabkan kontaminasi pada makanan. Kotoran yang menempel pada tangan selanjutnya dapat menyebabkan kontaminasi pada makanan.

Faktor pengetahuan lainnya yang juga berujung pada praktek penjamah yang kurang baik adalah masih terdapat penjamah yang memiliki kuku panjang, kotor dan menggunakan perhiasan seperti cincin. Hasil penelitian ini senada dengan penelitian Susanna (2003) yang menyatakan 36\% responden memiliki kuku yang kotor. Penelitian tersebut menyatakan ada hubungan yang bermakna antara kuku tangan penjamah makanan dengan kontaminasi makanan. Menurut Fathonah (2005) kuku tangan sering menjadi sumber kontaminan atau mengakibatkan kontaminasi silang. Penggunaan perhiasan cincin juga dapat menjadi media kontaminasi terhadap bahan makanan karena dimungkinkan perhiasan tersebut menjadi tempat akumulasi kotoran, sisa bahan makanan maupun mikroba yang tersembunyi pada sela-sela perhiasan.

\section{SIMPULAN DAN SARAN}

Sebanyak $72,3 \%$ responden memiliki tingkat pengetahuan tentang hygiene penjamah dengan kategori kurang. Sebanyak 58,5\% responden memiliki kategori praktek hygiene penjamah dengan kategori kurang baik. Hasil uji statistik disimpulkan terdapat hubungan yang signifikan antara tingkat pengetahuan dengan praktek hygiene penjamah makanan jajanan.

Saran disampaikan kepada pedagang sebagai penjamah makanan untuk meningkatkan tentang pengetahuan dan praktek yang baik mengenai hygiene penjamah melalui berbagai media informasi.

\section{DAFTAR PUSTAKA}

1. Adebukola, et al. 2015. Knowledge of food borne infection and food safety practices among local food handlers in Ijebu-Ode Local Government Area of Ogun State. Journal of Pbloc Health and Epidemiology. Vol.7(9), pp. 268273 , September 2015. https://doi.org/10.5897/JPHE2015.0 $\underline{758}$

2 Agustina, Febria; Rindit Pambayun; Fatmalina Febry;. Higiene Dan Sanitasi Pada Pedagang Makanan Jajanan Tradisional Di Lingkungan Sekolah Dasar Di Kelurahan Demang Lebar Daun Palembang. Jurnal Ilmu Kesehatan Masyarakat. No 1 Maret 2010.

3. Avrilinda, Sella Monica. 2016. Pengaruh Pengetahuan Dan Sikap Terhadap Perilaku Higiene Penjamah Makanan Di Kantin Sma Muhammadiyah 2 Surabaya . e-journal Boga, 
Volume 5, No. 2, Edisi Yudisium Periode Mei 2016, Hall-7. Jurnal mahasiswa.unesa ac.id/article/18700/48/article.

4. Budiyono; Hasrah Junaedi; Isnawati; Tri Wahyuningsih. Tingkat Pengetahuan Dan Praktik Penjamah Makanan Tentang Hygiene Dan Sanitasi Makanan Pada Warung Makan Di Tembalang Kota Semarang Tahun 2008. Jurnal Promosi Kesehatan Indonesia Vol. 4 / No. 1 / Januari 2009. https://media.neliti.com/media/p ublications/4929-ID-tingkatpengetahuan-dan-praktikpenjamah-makanan-tentanghygiene-dan-sanitasi-ma.pdf

5. Desiyanto, Fajar Ardi. Sitti Nur Djannah. Efektivitas Mencuci Tangan Menggunakan Cairan Pembersih Tangan Antiseptik (Hand Sanitizer ) Terhadap Jumlah Angka Kuman. KESMAS, Vol.7, No.2, September 2013, pp.55 112 ISSN:1978-0575

https://media.neliti.com/media/p ublications/24934-ID-

efektivitas-mencuci-tanganmenggunakan-cairan-pembersihtangan-antiseptik-hand-s.pdf

6. Fathonah, Siti. 2005, Higiene dan Sanitasi Makanan. Fakultas Teknik Universitas Negeri Semarang, Semarang.

7. Hapsari, Rahmawati Nila. 2013. Kontribusi Makanan Jajanan Terhadap Tingkat Kecukupan Asupan Energi Dan Protein Pada Anak Sekolah Yang Mendapat Pmt- As Di Sd Negeri Plalan 1 Kota Surakarta. Skripsi. Universitas Muhammadiyah Surakarta.
eprints.ums.ac.id/27111/13/NAS KAH_PUBLIKASI.pdf

8. Kepmenkes RI. 2013. Keputusan Menteri Kesehatan Republik Indonesia Nomor 942/Menkes/Sk/Vii/2003

Tentang Pedoman Persyaratan Hygiene Sanitasi Makanan Jajanan

9. Sari, Meidia Atika. Sulistiyani. Nikie Astorina Yunita Dewanti. Perbedaan Perilaku Penjamah Makanan Sebelum Dan Sesudah Mendapatkan Penyuluhan Higiene Sanitasi Makanan Pada Warung Makan Di Terminal Terboyo Semarang. Jurnal Kesehatan Masyarakat (EJournal). Volume 4, Nomor 5, Oktober 2016 (ISSN: 2356-

3346).http//ejournals1.undip.ac.id/index.php/jkm. https://media.neliti.com/media/p ublications/110979-IDperbedaan-perilaku-penjamahmakanan-sebe.pdf

10. Suryabudhi (2003).Cara Merawat Bayi dan Anak anak". Bandung : Alfabeta

11. Susanna, Dewi dan Budi Hartono. 2003, 'Pemantauan Kualitas Makanan Ketoprak dan Gado-Gado di Lingkungan Kampus UI Depok Melalui Pemeriksaan Bakteriologis'. Makara Seri Kesehatan 7(1) :2129.

12 Wang, Dantong, et al.Snacking Among US Children: Patterns Differ by Time of Day. Jurnal of Nutrition Education and Behavioral. Vol 48, issue 6, June 2016.

DOI: https://doi.org/10.1016/j.jneb.20 16.03.011 